\title{
Fight or Flight: \\ An Account of a Professor's First Year Obsession
}

\section{Raina J. León}

Saint Mary's College of California

\begin{abstract}
In this article, a junior faculty member explores her obsessions with the distribution of time in the areas of teaching, scholarship, service and personal life through an intensive analysis of an academic calendar, populated with data points in those areas. Through this analysis, she examines her first year and her own development as an academic.
\end{abstract}

Keywords: self study, first-year professor, education, inner life

Raina J. León is currently an assistant professor of education at Saint Mary's College of California. email: rj16@stmarys-ca.edu 
It's August 2011. I have been using my office for a little over a week.

I am absolutely terrified that someone will catch me. I am not doing what I am supposed to be doing. I am not even sure what I am supposed to be doing, but it is certainly not playing Bejewelled on my iPhone in my office. The door is partly closed, and perhaps that's why I jump in my chair at the sound of a door suddenly being opened. It's not mine; it's probably the associate dean's office. He's just next door, and his office seems to always be buzzing with folks coming in and out. It is accreditation visit time.

It's not my door, and still I find my heart racing. My head has focused on the knob. The phone rests in my hand, my playing finger still poised and ready to move another jewel into exploding glory. I am waiting to be caught tech-handed, and I realize that I have no excuse for what I assume is bad behavior for a professor.

I was a high school teacher. Now, I am a professor of education. I let that new identity unfold like a loosed red ribbon spool. Part of me wants to hold tight the end, follow until the spool can be captured and wound back to the beginning. Does one ever stop being a high school teacher? I wonder. Who is the professor in me?

In preparation for the first course I am teaching in my first appointment as an assistant professor, I have immersed myself in texts. That's what I am taking a break from for a moment a la Pomodoro Technique. Now, I share with you what Parker Palmer describes in The Courage to Teach, a look into this academic's inner life: (Palmer, 2010):

If identity and integrity are more fundamental to good teaching than technique and if we want to grow as teachers - we must do something alien to academic culture: we must talk to each other about our inner lives - risky stuff in a profession that fears the personal and seeks safety in the technical, the distant, the abstract (p. 12).

I was so recently panicked to the point of my heart racing, all rooted in the prospect of being proclaimed an academic fraud for play, as if play has no place in academia, as if I had no right to rest my mind in whatsoever way I found fit, as if I was bad, the bad professor long before I have even met my students.

It was a privileged position in which I found myself that August. A woman of color appointed as a tenure-track assistant professor in Education at a small, liberal arts college, I recognize now that I was and am something of an anomaly as the majority of faculty, particularly women faculty, if full-time, are not tenure-track (Banerji, 2006). Women are more likely to hold part-time positions at universities (Curtis, 2011). While the percentage of underrepresented minority faculty members is growing, it still remains low despite a growing commitment by universities to diversifying their campuses (Moreno, Smith, Clayton-Pedersen, Parker, \& Teraguchi, 2006). In a 2006 Latina/o Education Summit Report (Pérez Huber, et al, 2006), I saw this clearly delineated by numbers relating the reality of the United States educational pipeline. If 100 African American female students started in elementary school, only .3\% of them graduated with a doctorate. Of 100 Latinas, it was the same number: .3\%. When Latinas were divided by sub-groups (Chicana, Puerto Rican, Cuban, Dominican, and Salvadoran), that number 
remained the same: $.3 \%$. As a comparison, the number for white women is $.6 \%$ while the number for white men is $1.4 \%$.

I also differ from many of my colleagues in that I am part of an academic legacy. While we do not work in the same discipline, my mother is also an academic, recently tenured at a small college. Throughout most of my life, I have heard first-hand accounts of the difficulties that my mother faced as she sought out and received tenure, first at one university and then later at another. Still, even with this up close and personal exposure to academic life, I still was unprepared for my own first year, particularly in determining what a professor's work really is and should be.

Still, nearly four years ago, I experienced a deep-seated, summer-heated fear. Someone was going to ask me how I spent my days, and I would have to report on all I had done. There might be an inquisition, I panicked. [I had just come from Bavaria where you throw a stone at the medieval torture museums available for tour.] The university was investing in me, and what did they have to show for that investment?

I decided to quantify my life. To reduce the anxiety, I started keeping a calendar that listed every act that I completed in the day: committee meetings, program meetings, class preparation, and teaching. It started with that, but it didn't stop. At times even more obsessive, I would layer yellow Post-Its over my penned-in days that delineated the hours that I had spent on teaching, scholarship, and service that day. Sometimes, I listed how much time I had spent on watching television, generally my favorite mind-numbing shows. Face Off, Real Housewives of Atlanta, Bar Rescue, Chopped. Oh, there's a marathon going on of [any zombie-fying show]? Yes, please. It helped shut off my brain from busy days. I kept my door open as I worked. I was in and out of the office, sometimes over 14 hours in a day. I worked five days a week and at least one weekend a month. In October 2011, I worked every day, including weekends.

Within a few months of beginning this recording practice - a practice I continued for my first three years as a professor - I started to ask myself questions. I was easing into the role, but I still felt this urge to record. What might I learn about myself? What might it reveal about negotiating a balance between teaching, scholarship, service, and a personal life? At the end of the first year - indeed in the summer after the academic year for three years - I conducted an analysis based on the calendar. To aid in my understanding of my development as an academic, I assigned value of one to each activity that could be filed under the aforementioned headings. In some cases, one activity received a value under multiple categories. For example, work on the creation of educational technology workshops was categorized under scholarship and service as it represented a presentation of my scholarship as well as a service to the local community of Catholic schools. I became obsessed with tallies and categories.

After assigning a value of one to each activity, the number of teaching, service and scholarship activities were counted. A total of activities per month and per category was then noted. With these values (see Table 1), the percentage of activities under the overall categories of teaching, service and scholarship during the academic year as well as the percentage of activities in those categories per month of the academic year were determined. In addition to the three categories most aligned to the academic life, I also developed a separate category, personal, to encompass specific notations of activities outside of academic life. Personal activities might include doctor appointments, poetry submissions, visits from out-of-town friends and family, lunch meetings with friends, 
dinner parties, watching television, and dates. I determined that this would be valuable in my analysis so as to see how and if I had effectively managed to balance my professional goals with personal needs. With each tick and the analysis of its fit in the four categories, I gained control: this was how I would show my value to the institution and how I would learn, too.

Table 1. 2011-2012 Analysis of First Year Professor's Academic Calendar

\begin{tabular}{|l|l|l|l|l|l|l|l|l|l|l|}
\hline & Aug. & Sept. & Oct. & Nov. & Dec. & Jan. & Feb. & Mar. & Apr. & May \\
\hline Teaching & $61 \%$ & $28 \%$ & $35 \%$ & $45 \%$ & $24 \%$ & $50 \%$ & $22 \%$ & $27 \%$ & $28 \%$ & $24 \%$ \\
& 27 & 35 & 53 & 64 & 13 & 62 & 52 & 52 & 50 & 44 \\
\hline Service & $7 \%$ & $41 \%$ & $26 \%$ & $22 \%$ & $26 \%$ & $14 \%$ & $27 \%$ & $22 \%$ & $21 \%$ & $\begin{array}{l}31 \% \\
57\end{array}$ \\
& 3 & 51 & 38 & 31 & 14 & 17 & 39 & 43 & 38 & 57 \\
\hline Scholarship & $7 \%$ & $29 \%$ & $39 \%$ & $27 \%$ & $37 \%$ & $29 \%$ & $39 \%$ & $35 \%$ & $29 \%$ & $17 \%$ \\
& 3 & 36 & 57 & 38 & 20 & 36 & 55 & 67 & 53 & 32 \\
\hline Personal & $25 \%$ & $2 \%$ & & $5 \%$ & $13 \%$ & $8 \%$ & $12 \%$ & $17 \%$ & $22 \%$ & $29 \%$ \\
& 11 & 3 & 0 & 8 & 7 & 10 & 17 & 32 & 39 & 54 \\
\hline $\begin{array}{l}\text { Total } \\
1341\end{array}$ & 44 & 125 & 148 & 141 & 54 & 125 & 143 & 194 & 180 & 187 \\
\hline
\end{tabular}

*Not all percent values total to 100 due to rounding

With scholarly distance, my anxiety reduced. In conducting an analysis of the 2011-2012 calendar, I expected that much of my time would have been devoted to service, but this was not the case. Service activities only comprised $24.7 \%$ of my work in the 2011-2012 academic year. Indeed, only two of the 10 months (September at $40.8 \%$ and May at 30.5\%) saw service as a significant category in my professorial work. Looking back and comparing my service then to now, it makes perfect sense. I had no connections at the university. I had moved from Germany to the Bay Area, a large expanse of communities to which I had no connection. Those relationships took time to build. In my second year of this analysis, service was the strongest category. My conclusion is that it took me about a year to build the initial contacts to engage in service.

Teaching, it turned out, held the largest sway in my first year as a professor. In that fearsome August, $61 \%$ of my time was devoted to teaching, which makes sense. I was teaching totally new courses, learning new texts, working in a new role. I was preparing as quickly as I possibly could to meet the students who would, within a year, be high school teachers, a position that I had just left. Overall, teaching made up $32 \%$ of my time for that academic year.

Scholarship was the second highest category at $30 \%$ for that academic year. I was working on my second book, which was released in my third year of service. As I didn't have as many service commitments, I had time then to develop scholarship plans and do a great deal of writing. I submitted widely to conferences and received a number of 
acceptances, which led to more scholarly opportunities in my second year of service. I was planting fruit trees in that first year that only began to shoot up in the second year. In the third year, I began to harvest. In this fourth year, I am planting a new orchard.

What was most surprising to me in that summer of 2012 when I looked at the calendar was how little of a personal life I had. There was one month, October, in which I noted no activities that would fit under this category. If following the preceding months, I went from devoting $25 \%$ of my time to personal development in August to $2 \%$ of my time in that same category in September to none of my time in that area in October. It follows that in August I may have given more time to establishing relationships in a new locale with friends that I had known from previous moves and that over time I became increasingly focused on my career. Following this category over time intrigued me in that it began to reverse as the personal became increasingly more important and more balanced in relation to the other categories. Indeed, by April, the four categories were most balanced.

Still, it makes sense that the personal made up only $13 \%$ of my time overall for the academic year. I had moved from one country back to my country of origin, changing careers in the field of education. I had to learn a new institution, new community, and new standards. I moved to California just as the Common Core State Standards were starting to be adopted. I had no previous work experience as a full time professor in education. My scholarship had primarily been as a poet, not as a teacher educator. I also was hired into a department that was not prepared, at the time, to mentor a new faculty member, being as many of the faculty were semi-retired within my program. I had to figure out a great deal on my own. I happened to have received a second position as a resident director; living on campus allowed me to attend undergraduate and graduate co-curricular programming. If there was a reading group, film, discussion, or event on campus, I was going. I learned about funding opportunities and outside supports early.

I had to learn quickly in that first year; I had to hustle. I found myself often thinking of my father's lessons to me as a child: You are poor, a woman, African American, Puerto Rican. No one is going to help you; you have to help you. You have to be better, work ten times harder. And not just for you, for the family. You can't dishonor $u s$. He said those things to teach me to fight. In my first year as a professor, I started in fear. Instinctually, when situationally-prodded to fight or flight, I went to fight. It started with numbers. It went on to reflection. Since that first year, I have used the tables about my experience in rank and tenure documents, talking about my goals for the future based on my quantitative analysis of where I had been. In the first year, I emphasized teaching. In the second, the emphasis was service. In the third, scholarship had a primary place in my work.

In this fourth year, I am emphasizing balance. I no longer keep the calendar. I no longer fear, because I feel comfortable in who I am as professor in this place and in this time. It took a lot of reflection, support from other faculty of color peers and mentors as well as professional allies, and a lot of sense-making conversations with my mother (again, another academic of color with whom I can speak the real-real talk) to get there. I no longer play Bejewelled, though I still enjoy all of the television shows I listed.

I still work hard. I continue to risk, even in just telling this story. I will not fear.

I look forward to August with joy. 


\section{References}

Banerji, S. (2006). AAUP: Women Professors Lag in Tenure, Salary. Diverse Issues in Higher Education, 23(20), 27.

Curtis, J. (2011). Persistent Inequity: Gender and Academic Employment. Prepared for "New Voices in Pay Equity" An Event for Equal Pay Day, April 11, 2011. Retrieved July 10, 2012, from http://www.aaup.org/NR/rdonlyres/08E023ABE6D8-4DBD-99A0-24E5EB73A760/0/persistent_inequity.pdf

Moreno, J. F., D. G. Smith, A. R. Clayton-Pedersen, S. Parker, and D. H. Teraguchi. (2006). The revolving door for underrepresented minority faculty in higher education. San Francisco: The James Irvine Foundation. Retrieved July 19, 2012, from www.irvine.org/assets/pdf/pubs/education/insight_Revolving_Door.pdf.

Palmer, P. (2010). The courage to teach: Exploring the inner landscape of a teacher's life. San Francisco, Calif: Jossey-Bass.

Pérez Huber, L., Huidor, O., Malagón, M., Sánchez, G., and Solórzano, D. (2006). Falling through the cracks: Critical transitions in the Latina/o educational pipeline. UCLA Chicano Studies Research Center Report, (7). 